\title{
Perception and Realities of the Impact of Global Changes on Water Resources and Agricultural Practices - Preliminary Findings of AGloCAP Project in Indrawati Basin, Nepal
}

Suman Sijapati and Dinesh Bhatt

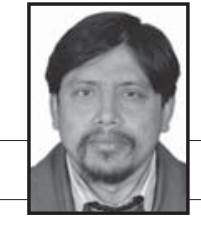

Suman Sijapati

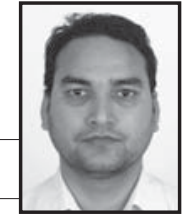

Dinesh Bhatt

\begin{abstract}
This paper presents the trends of precipitation and temperature in the Indrawati basin, Nepal and tries to compare it with the experiences and perceptions of the local farming communities. It forms part of the preliminary findings from the AGloCAP (Adaptation to Global Change in Agricultural Practices) project under which field data is being collected from selected sample sites in the basin. The impact of global changes on agricultural practices and underlying socio-economic variables has been analysed by characterizing the basin into different agro-ecological zones.

The preliminary analysis of field data reveal that global changes is having diverse impact on agriculture ranging from change in agro-climatic condition, shifting of cropping areas, change in timing of agricultural activities, change in input levels, outbreak of disease and pests. The farmers' perceptions of these changes, although sometime found to be a bit exaggerated and possessing their own interpretations, were observed to be very much in line with the identified trends of climatic factors. Similarly, it was also observed that in addition to the changing climatic condition, the underlying social, economical and institutional drivers have a remarkable influence on agricultural production in the region and that global change is first impacting those who are already marginal.
\end{abstract}

Key words: Global changes, farmer's perception, agricultural practices, impact, Indrawati basin, Nepal

\section{Introduction}

griculture systems have been one of the main Asubjects of analysis to understand the impact of both climatic variability and climatic change. This is of particular importance for the agriculture based population living in the developing world with small land holders and subsistence farming for whom on-farm agriculture and off-farm agricultural labour provide the main source of income (Ito and Kurosaki 2009). Moreover, more than 800 million people are already undernourished (UN Millennium Project 2005) in the developing world and climate change is likely to cause yield reduction for most of the staple crops, with South Asia being the most susceptible region (Nelson, Rosegrant et al 2009). On the other hand, increasing population and high rates of natural resource degradation are expected to continue to have high rates of poverty and food insecurity for Asia, Sub-Saharan Africa and Latin America (Fischer, Shah and van Velthuizen 2002).

With the growing concerns about global changes, many researchers around the world have tried to identify the effect of the climatic factor on the yield of the agricultural products (Gunduz, Ceyhan and Bayramoghu 2011). However, in addition to the biophysical process the socio-economic drivers like GDP, availability of land and labour, agricultural technology, infrastructure, population involved in farming, land tenure, capital also play a significant role in the determination of crop yield and productivity. Unfortunately, only a limited literature is available on how socio-economic factors may buffer or exacerbate the effects of climate change on crop productivity.

Moreover, since the process of making agricultural decisions and climate cannot be isolated from the culturally constituted ways of seeing, knowing and valuing the world, it is very crucial to understand how the local communities perceive these changes. In order to understand how humans would respond to climate change, it is essential to study people's perceptions of climate and the environment in general (Vedwan 2001). This is expected to have great significance especially in terms of suggesting adaption measures that are appropriate and acceptable to the local communities.

The main impetus of this paper is on drawing a comparison between the farmer's perception and the facts revealed by the scientific analysis of data pertaining to climate change and its interface with water availability and crop management practices in Indrawati basin of Nepal. More specifically, we computed the trends in indices of rainfall and temperature in the region and then analysed the influence of management practices and socioeconomic variables on crop yield of the region to see how it compares with the experiences and perception of the local community.

\section{Study area}

The Indrawati basin falls under the alpine and subtropical climate zone with an elevation range from $616 \mathrm{~m}$ to $6,359 \mathrm{~m}$ above mean sea level (Figure 1) having drainage area of $1,239 \mathrm{~km}^{2}$. The average annual rainfall in the basin ranges from $3,874 \mathrm{~mm}$ at the higher elevation (Sarmathang) to about $1,128 \mathrm{~mm}$ at the lower elevation (Dolalghat) with high spatial and temporal variation. Regarding runoff, a study by Rajkarnikar (2000) shows that water flow in the major sub-basins has significant seasonal variation with about $80 \%$ of the total annual river flow occurring in the monsoon season (June to September). In terms of land use, $38 \%$ of the area is under some form of cultivation while $31 \%$ is preserved area and $29 \%$ is under natural vegetation.

\section{Data and Methodology}

Using all available climatic data of the area, firstly an attempt was made to carry out an in-depth analysis of the trend of the climatic variable (mainly, rainfall and temperature) of the study area. Then, this result was compared with the outcome of the analysis of socio- 


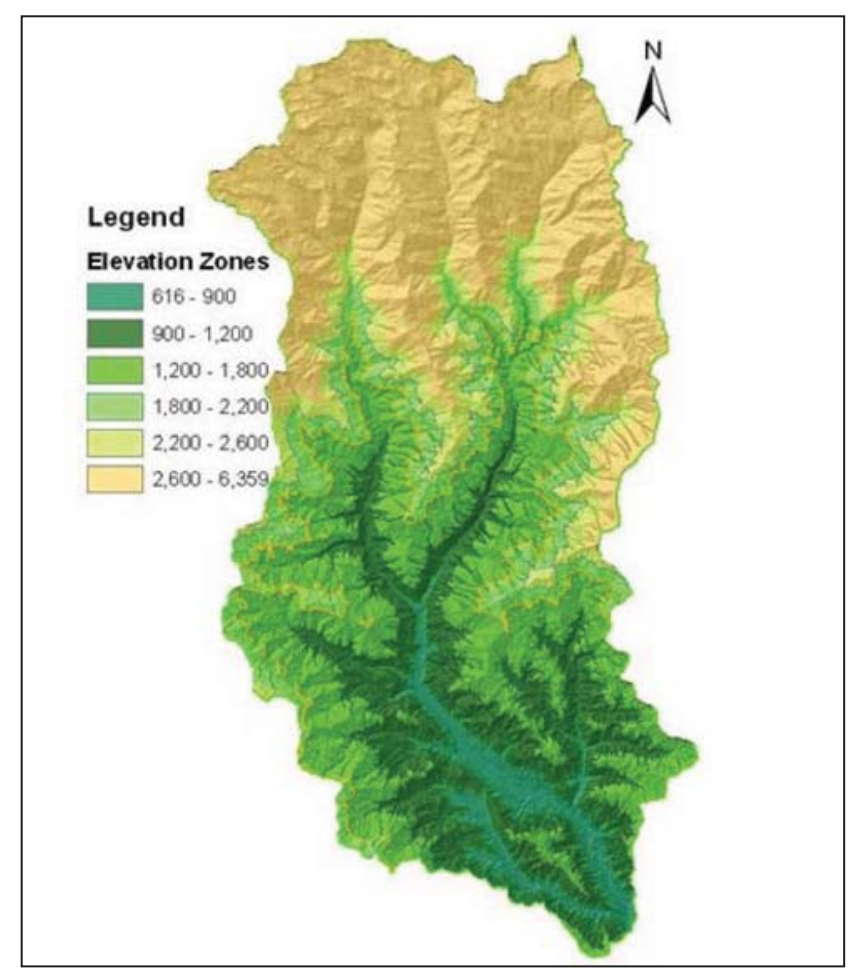

Figure 1. Designation of Different Elevation Zones Based on Cropping Pattern (Elevation in Meters above $\mathrm{msl}$ ).

economic and agricultural data collected from the sample sites in the basin.

\section{Database of climatic factors}

Daily precipitation data at 12 meteorological stations and daily temperature data at two stations were used (Figure 2). About 30 years data was used for the analysis, 1978-2008 for precipitation and 1979-2008 for

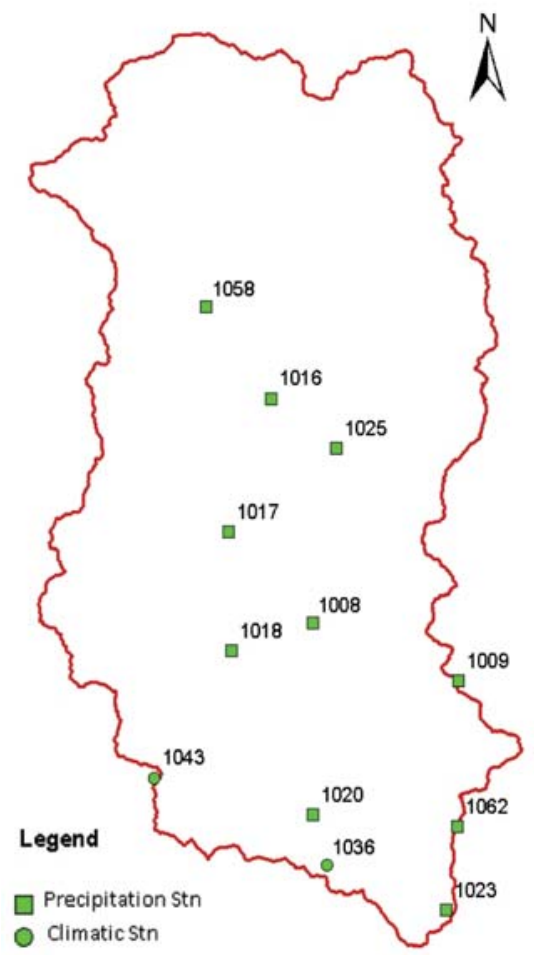

Figure 2. Meteorological Stations in Indrawati Basin. temperature. The missing values were replaced with the monthly average.

\section{Rainfall and temperature indices}

Seven indices for rainfall and temperature each were estimated in order to analyse the change in average and extreme regime of precipitation and temperature (Table 1) using the STARDEX software available at www.cru.uea. ac.uk/cru/projects/stardex/. Each indices are calculated on seasonal and on an annual basis. Many of the selected indices have been used in the previous studies $(\mathrm{Hu}$, Maskey and Uhlenbrook 2011; Moberg and Jones 2005; López-Moreno, Vicente-Serrano et al 2009).

\begin{tabular}{|l|l|l|}
\hline $\begin{array}{c}\text { S. } \\
\text { No. }\end{array}$ & Indices & \multicolumn{1}{c|}{ Description } \\
\hline 1 & Txav & Mean daily maximum temperature $\left({ }^{\circ} \mathrm{C}\right)$ \\
\hline 2 & Tnav & Mean daily minimum temperature $\left({ }^{\circ} \mathrm{C}\right)$ \\
\hline 3 & Trav & Mean daily diurnal temperature range $\left({ }^{\circ} \mathrm{C}\right)$ \\
\hline 4 & Txq90 & $\begin{array}{l}90 \text { th percentile of daily maximum temperature } \\
\text { (hot days) }\left({ }^{\circ} \mathrm{C}\right)\end{array}$ \\
\hline 5 & Tnq10 & $\begin{array}{l}10 \text { th percentile of daily minimum temperature } \\
\text { (cold nights) }\left({ }^{\circ} \mathrm{C}\right)\end{array}$ \\
\hline 6 & Txf90 & $\%$ days T maximum greater than 90 th percentile \\
\hline 7 & Tnf10 & $\%$ days T minimum < 10 th percentile \\
\hline 8 & Pav & Mean climatological precipitation (mm/day) \\
\hline 9 & Pxcdd & Maximum number of consecutive dry days (days) \\
\hline 10 & Pxcwd & $\begin{array}{l}\text { Maximum number of consecutive wet days } \\
\text { (days) }\end{array}$ \\
\hline 11 & Px5d & Greatest five days total rainfall (mm) \\
\hline 12 & Pint & Simple daily intensity (rain per rainday) \\
\hline 13 & Pfl90 & $\begin{array}{l}\% \text { of total rainfall events greater than long term } \\
90 t h \text { percentile }(\%)\end{array}$ \\
\hline 14 & Pnl90 & $\begin{array}{l}\text { Number of events greater than long term } 90 \text { th } \\
\text { percentile (days) }\end{array}$ \\
\hline
\end{tabular}

Table 1. Temperature and Rainfall Indices Used for Analysis.

\section{Climatic trend analysis}

Trend analysis of the seasonal indices was performed using non-parametric Mann-Kendall statistic test (Mann 1945; Kendall 1975) at 10\% significant level. The test statistics $\mathrm{S}$ is given by:

$$
\begin{aligned}
& S=\sum_{i=2}^{n} \sum_{j=1}^{i-1} \operatorname{sign}\left(x_{i}-x_{j}\right) \\
& \operatorname{sign}\left(x_{i}-x_{j}\right)=\left\{\begin{array}{lll}
1 & \text { if } & x_{i}>x_{j} \\
0 & \text { if } & x_{i}=x_{j} \\
-1 & \text { if } & x_{i}<x_{j}
\end{array}\right.
\end{aligned}
$$

Where,

Under the null hypothesis of randomness the $\mathrm{S}$ has a normal distribution with the mean value $\mu_{\mathrm{s}}$ and variance $\sigma_{\mathrm{s}}^{2}$ given by:

$$
\begin{aligned}
& \sigma_{s}^{2}=\frac{n(n-1)(2 n+5)}{18} \\
& \mu_{s}=0
\end{aligned}
$$


The standardised test statistics Z is computed as:

$$
\begin{aligned}
& Z=\frac{S+1}{\sqrt{\operatorname{Var}(S)}} \text { for } \mathrm{s}>0 \\
& Z=0 \text { for } \mathrm{s}=0 \\
& Z=\frac{S-1}{\sqrt{\operatorname{Var}(S)}} \text { for } \mathrm{s}<0
\end{aligned}
$$

The Sen Slope Estimator (Sen 1968) was used to calculate the magnitude of the trend because of its robustness against extreme outliers (Hirsch, Slack and Smith 1982).

\section{Data of farmers' perception, agricultural practices and socio-economic variables}

To determine the perception of the local farming communities regarding the climate change and the influence of socio-economic drivers and agricultural practices, field work involving questionnaire survey, focus groups and direct interactions was carried out with the farmers of the study area. Data regarding agricultural practices being adapted by the local communities, underlying socio-economic conditions of the basin is being collected from 13 sample sites in the basin. These sample sites were selected to represent different agro ecological zones with elevation ranging from $770 \mathrm{~m}$ to $2,593 \mathrm{~m}$ and representing irrigated and rain-fed agriculture system.

Figure 3 shows the locations of the sample sites.

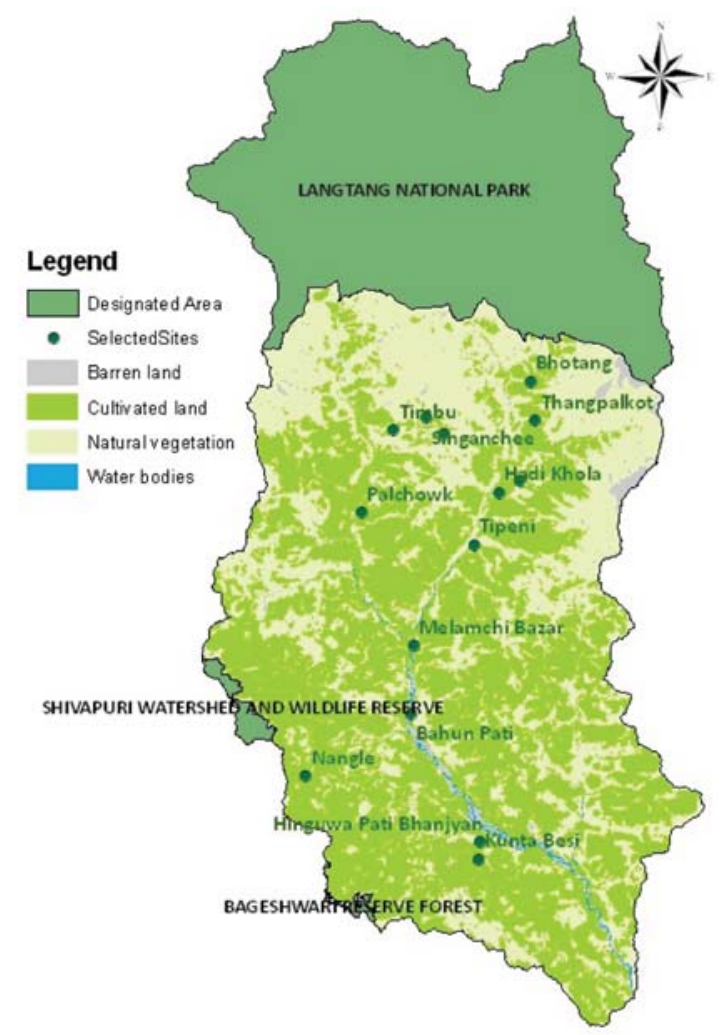

Figure 3. Selected Sample Sites in Indrawati Basin for Data Collection.

\section{Analysis of production scenarios}

Finally, the prevailing production systems of staple crops and the underlying social and economic conditions leading to the different production scenarios were analysed. Production trends in different agri-ecological zones and the impact of different production and socioeconomic variable were examined.

\section{Results and Discussion \\ Trends in precipitation and temperature regimes}

Change per decade in precipitation and temperature indices are presented in Table 2 and Table 3.

\section{Precipitation}

As a whole, no pronounced trend was observed in the precipitation regime of the basin at $10 \%$ significant level. Trends in consecutive dry days are more marked than other indices (Table 2).

Consecutive dry days (Pxcdd) were found to be increasing for about $34 \%$ of the stations in the annual analysis. On the seasonal analysis, Pxcdd in winter and autumn were found to be increasing, with more pronounced trend in Winter (9day/decade). But, no significant trend were identified for spring and summer.

For consecutive wet days (Pxcwd), no significant trend was detected for most of the stations analysed. In the seasonal analysis, the trend was more pronounced for summer season with an increase of 10 day/decade for $8 \%$ of the stations and 4 day/decade decrease for the same percentage of stations.

Rainfall per rainy day (Pint) has increasing trend for winter, spring and autumn for some stations, with maximum percent of stations (16\%) in spring and maximum magnitude of trend of $2.48 \mathrm{~mm} /$ decade in autumn. In contrast, decreasing trend of $4.7 \mathrm{~mm} /$ decade is observed for $8 \%$ of the stations in summer.

The trend of the greatest five day total rainfall (Px5d) is significant for spring season with $25 \%$ of the stations showing increased trend with the magnitude ranging from $10-15 \mathrm{~mm} /$ decade. In contrast $8 \%$ of the stations shows decreasing trend in summer with the magnitude $32.62 \mathrm{~mm} /$ decade. The magnitude of increasing as well as decreasing trend in winter is small as compared to spring and summer. While, autumn shows no significant trend.

For pnl9o, on annual analysis, about $16 \%$ of the stations have decreasing trend, while the remaining have no significant trend. In the seasonal analysis, for summer the decreasing trend is about two to three day/decade for about $16 \%$ of stations. While the magnitude of trend was insignificant for the other seasons.

\section{Temperature}

Obviously, only two climatic stations can not represent the whole of Indrawati basin. However, temperature indices of these stations can still provide some indication of the historical temperature trend in the basin. Mean maximum temperature and mean diurinal temperature has increasing trend at $10 \%$ significance level in annual analysis. Similarly, seasonal analysis also indicates increasing trend during mainly during spring and autumn. 


\begin{tabular}{|c|c|c|c|c|c|c|c|c|c|c|c|c|c|c|c|c|c|c|c|c|c|c|c|c|c|}
\hline \multirow[t]{2}{*}{$\begin{array}{l}\text { Stn. } \\
\text { ID }\end{array}$} & \multicolumn{5}{|c|}{$\begin{array}{l}\text { Maximum Number of Dry Days } \\
\text { (Pxcdd(day/decade)) }\end{array}$} & \multicolumn{5}{|c|}{$\begin{array}{l}\text { Maximum Number of Consecutive Wet } \\
\text { Days (Pxcwd(days/decade)) }\end{array}$} & \multicolumn{5}{|c|}{$\begin{array}{l}\text { Simple Daily Intensity (Rain per rain } \\
\text { day) (Pint(mm/decade)) }\end{array}$} & \multicolumn{5}{|c|}{$\begin{array}{l}\text { Graters } 5 \text { days Total Rainfall (Px5d(mm/ } \\
\text { decade)) }\end{array}$} & \multicolumn{5}{|c|}{$\begin{array}{l}\text { Number of events Greater than } \\
\text { Long term 90th Percentile (days) } \\
\text { (Pn|90(days/decade)) }\end{array}$} \\
\hline & DJF & & & SON & & DJF & & & SON & Annual & DJF & & & SON & & DJF & & JJA & & Annual & DJF & MAM & $\mathrm{JJA}$ & SON & Annual \\
\hline 1008 & 6.36 & (1) & 0.00 & 5.83 & 9.29 & 0.00 & & 0.00 & -0.38 & -0.67 & 0.55 & & 0.23 & 0.77 & & -2.87 & 11.39 & -1.60 & T. & -2.00 & 0.00 & 0.38 & 0.48 & 0.43 & 0.56 \\
\hline 1009 & 2.73 & 3.33 & 0.00 & 5.00 & 1043 & 0.00 & & & -0.80 & -2.94 & 1.41 & & & 2.48 & & .40 & & & & & 0.00 & 0.56 & 0.00 & 0.00 & \\
\hline 1016 & 00 & & & 25 & & & & & & & & & & & & & & & & & 0.00 & & -2.86 & -1.00 & \\
\hline 1017 & J & 0.00 & 0.00 & 3.93 & 0.10 & 0.00 & & & -1.11 & -4.29 & 0.62 & & -0.50 & 1.53 & & -2.00 & 9.80 & 0.62 & -7.88 & -2.33 & 0.00 & 0.91 & 0.00 & 0.00 & \\
\hline 1018 & 5.00 & -1.05 & 0.00 & 1.11 & 6.43 & 0.00 & 0.00 & -0.45 & -0.91 & -0.50 & -0.04 & 0.19 & -0.45 & 0.64 & 0.05 & -4.67 & 1.08 & 7.00 & -10.73 & 3.43 & 0.00 & 0.00 & 0.00 & 0.00 & -050 \\
\hline 1020 & -3.70 & 1.61 & 0.45 & 3.81 & 2.00 & 0.71 & 0.00 & & 0.00 & -0.87 & 0.33 & & -0.76 & -1.02 & -0.26 & 4.09 & & -10.75 & & -6.00 & 0.00 & 0.00 & 0.00 & 0.00 & \\
\hline 1023 & 4.55 & -1.18 & 0.00 & 2.80 & 6.25 & 0.00 & & & & 0.00 & -1.16 & & -0.37 & -0.44 & $\begin{array}{l}-0.05 \\
\end{array}$ & -5.52 & & & -3.63 & & 0.00 & 0.36 & .00 & 0.00 & \\
\hline 1025 & 071 & Tor & 0.00 & -0.69 & 3.33 & 0.00 & 0.00 & & 1.76 & 3.50 & 1.07 & & -1.31 & 0.97 & 0,01 & 3.79 & . & -17.42 & 18.63 & 11.57 & 0.00 & 0.00 & -1.90 & 0.00 & \\
\hline 1036 & 8.67 & 0.00 & 0.63 & 0.00 & 5.86 & 0.00 & 0.00 & & 0.00 & -0.77 & -0.66 & -0.25 & & 0.46 & & -7.58 & & & & & 0.00 & 0.00 & 0.00 & 0.00 & -0.59 \\
\hline 1043 & 6.00 & -1.50 & -0.59 & -2.86 & 3.33 & 0.00 & 2.00 & 1.00 & 0.00 & 1.11 & 1.48 & 0.39 & -0.72 & 0.21 & ono & 3.75 & 11.86 & 20.76 & & 17.65 & 0.00 & 0.63 & 0.00 & 0.00 & \\
\hline 1058 & 7.04 & 2,01 & 0.00 & 0.91 & 3.75 & 0.00 & 0.59 & 10.00 & 0.00 & 11.43 & -0.33 & -0.12 & 0.59 & 0.31 & -0.24 & -0.72 & 4.86 & -7.39 & 9.60 & -9.86 & 0.00 & 0.00 & 0.01 & 0.00 & 1.82 \\
\hline 1062 & 3.83 & -3.33 & 0.63 & 0.63 & 4.00 & 0.00 & 0.56 & & 0.00 & 0.00 & -0.89 & -0.66 & -0.42 & 0.43 & & \begin{tabular}{|l|}
-3.39 \\
\end{tabular} & -1.31 & 11.56 & -4.20 & -9.64 & 0.00 & 0.00 & 0.00 & 0.00 & \\
\hline
\end{tabular}

Table 2. Change per Decade in the Precipitation Indices. ${ }^{1}$ (Bold are Significant at 10\%; DJF-December, January, February; MAM- March, April, May; JJAJune, July, August; SON-September, October, November).

\begin{tabular}{|c|c|c|c|c|c|c|c|c|}
\hline $\begin{array}{l}\text { Stn. ID } \\
\text { (Elev.) }\end{array}$ & Season & $\begin{array}{l}\text { Mean Daily Maximum } \\
\text { Tempertaure (Txav } \\
\left({ }^{\circ} \mathrm{C} / \text { decade)) }\right.\end{array}$ & $\begin{array}{l}\text { Mean Daily Minimum } \\
\text { Temperature (Tnav } \\
\left({ }^{\circ} \mathrm{C} / \text { decade)) }\right.\end{array}$ & $\begin{array}{l}\text { Mean Daily Seasonal } \\
\text { Temperature (Trav } \\
\left({ }^{\circ} \mathrm{C} / \text { decade) }\right)\end{array}$ & $\begin{array}{l}\text { 90th Percentile of } \\
\text { Daily Maximum Tem- } \\
\text { perature (holydays) } \\
\left(\text { Txq90 }\left({ }^{\circ} \mathrm{C} / \text { decade) }\right)\right.\end{array}$ & $\begin{array}{l}\text { 10th Percentile of } \\
\text { Daily Minimum Tem- } \\
\text { perature (coldnights) } \\
\text { (Tnq10 ( }{ }^{\circ} \mathrm{C} / \text { decade)) }\end{array}$ & $\begin{array}{l}\text { \% Daily Temperature } \\
\text { Greater than } 90^{\text {th }} \\
\text { Percentile (Txf90 (\%/ } \\
\text { decade)) }\end{array}$ & $\begin{array}{c}\% \text { Daily Temperature } \\
\text { minimum }<10 \text { th } \\
\text { Percentile (Tnf10 (\%/ } \\
\text { decade)) }\end{array}$ \\
\hline \multirow{5}{*}{$\begin{array}{c}1036 \\
(865 \mathrm{~m})\end{array}$} & DJF & 0.30 & -0.29 & 0.63 & 0.35 & -0.21 & 0.01 & 0.02 \\
\hline & MAM & 0.31 & -0.26 & 0.44 & 0.12 & -0.07 & 0.01 & 0.02 \\
\hline & JJA & 0.25 & -0.05 & 0.31 & 0.15 & -0.04 & 0.02 & 0.00 \\
\hline & SON & 0.33 & 0.03 & 0.34 & 0.40 & 0.00 & 0.04 & 0.00 \\
\hline & Annual & 0.33 & -0.12 & 0.43 & 0.10 & 0.00 & 0.02 & 0.01 \\
\hline \multirow{5}{*}{$\begin{array}{c}1043 \\
(2163 \mathrm{~m})\end{array}$} & DJF & 0.74 & 0.30 & 0.57 & 0.76 & 0.11 & 0.05 & -0.02 \\
\hline & MAM & 0.24 & 0.00 & 0.36 & 0.40 & 0.13 & 0.02 & 0.00 \\
\hline & JJA & -0.13 & 0.03 & 0.06 & -0.19 & 0.00 & 0.00 & 0.00 \\
\hline & SON & 0.60 & 0.12 & 0.52 & 0.41 & 0.18 & 0.06 & -0.01 \\
\hline & Annual & 0.39 & 0.06 & 0.37 & 0.00 & 0.16 & 0.03 & 0.00 \\
\hline
\end{tabular}

Table 3. Change per Decade in the Temperature Indices (Bold are Significant at 10\%).

Trends in 9oth percentile maximum temperature and percentage of days with maximum temperature greater than 9oth percentile were significant only during particular season. For minimum temperature, decreasing trend was observed for spring in one of the station. However, 10th percentile minimum temperature and percentage of days minimum temperature is less than 1oth percentile do not indicate any significant trend in annual and seasonal analysis (Table 3).

As a whole, trend in mean maximum temperature and mean diurinal temperature were more pronounced.

For maximum temperature (Txav), the annual analysis shows increasing trend for both the stations. Additionally, the trend was more pronounced at higher elevation. Similarly, during winter and autumn season the trend was more significant at higher elevation. While, during summer, station at lower elevation shows increasing trend. No significant trend was detected in spring season. In contrast, the increasing trend in the diurinal temperature range on annual analysis was more pronounced at lower elevation. Furthermore, on seasonal analysis, increasing trend was detected during all the four season at lower elevation. While, for the station at the higher elevation no significant trend were identified during spring and summer.

Minimum temperature (Tnav) has no significant trend for both annual and seasonal analysis except for spring where station at lower elevation shows decreasing trend.

9oth percentile maximum temperature (Txq90) has increasing trend for winter and autumn. Stronger trend has been observed during winter and at higher elevation but no significant trend exists during spring and summer. Similarly, no significant trend has been detected for 1oth percentile minimum temperature and percentage of days minimum temperature is less than 1oth percentile.

\section{Experiences and Perception of the Local Communities about Climate Change Historical changes in agricultural practices}

It was revealed that the population in the basin increased significantly since the 1970s. This resulted in a

1 Out of the seven indices analyzed, five indices which shows relatively stronger trend are presented. 
gradual increase in the number of houses and a gradual expansion of agricultural area. Cropping intensity gradually increased. Early paddy was introduced about 20 years ago in low elevation areas where water was available. However, the farmers still depended on traditional crop varieties and practices, and agriculture was only a means of subsistence.

Improvements in agricultural practices in the area are reported to have taken place only from the early to mid-9os when the products from the area started getting commercial value in nearby markets near Kathmandu valley with its booming population. This resulted in gradual commercialization of agriculture. Improved varieties of different crops were introduced that gave higher yields and could be harvested in a shorter period. High yielding varieties of rice, hybrid corns and improved varieties of vegetables gradually found place in the farmers' field. This also led to the use of insecticides and pesticides as these varieties were found to be more susceptible to diseases and attacks by insects. Even though traditional varieties of maize and potato is prevailing in the area since ancient times, hybrid variety of maize and improved variety of potatoes is said to have become more popular since the last 10 years. Significant shifts were also reported by the farmers in terms of timing of the different crops.

\section{Farmer's perceptions and experiences of water resources availability}

Data collected from the farmers about water availability in the different sites revealed an interesting finding that the sites can basically be divided into three categories in terms of their water sources: major (perennial) rivers, local sources and rain-fed. Those areas which extract water from major perennial rivers seem to be unaffected in terms of water availability through time (probably because they were able to extract more water as required). However, irrigated areas depending on local water sources have reported a decreasing trend in term of water availability. Table 4 shows the scenario of water availability in the sample sites.

\begin{tabular}{|l|l|l|l|l|}
\hline $\begin{array}{c}\text { S. } \\
\text { No. }\end{array}$ & Sample sites & \multicolumn{1}{|c|}{$\begin{array}{l}\text { Water } \\
\text { source }\end{array}$} & Availability & \multicolumn{1}{|c|}{ Trend } \\
\hline 1. & Kunta Besi & Cha River & $\begin{array}{l}\text { Enough/deficit } \\
\text { (at tail) }\end{array}$ & Decreasing \\
\hline 2. & Hinguwa Pati & Local sources & Insufficient & Decreasing \\
\hline 3. & Bahun Pati & Sindhu River & Enough & $\begin{array}{l}\text { Stable; recently } \\
\text { decreasing }\end{array}$ \\
\hline 4. & Melamchi Bazar & $\begin{array}{l}\text { Melamchi } \\
\text { River }\end{array}$ & Enough & $\begin{array}{l}\text { Stable; recently } \\
\text { decreasing }\end{array}$ \\
\hline 5. & Tipeni & $\begin{array}{l}\text { Mahadev } \\
\text { River }\end{array}$ & $\begin{array}{l}\text { Enough / } \\
\text { deficit (at tail) }\end{array}$ & Decreasing \\
\hline 6. & Kiul & Local Sources & Mostly deficit & Decreasing \\
\hline 7. & Thangpal Dhap & Local river & Enough to low & Decreasing \\
\hline 8. & Bhotang & None & Rainfed & N.A. \\
\hline 9. & Thangpal kot & Chimpti River & Insufficient & $\begin{array}{l}\text { Stable; recently } \\
\text { decreasing }\end{array}$ \\
\hline 10. & Nangle & None & Rainfed & N.A. \\
\hline 11. & Palchowk (Kiul) & Local sources & Enough to low & Decreasing \\
\hline 12. & Timbu & Local sources & Enough to low & Decreasing \\
\hline 13. & Shermathang & None & Rainfed & N.A. \\
\hline
\end{tabular}

Table 4. Scenario of Water Resources Availability.

\section{Perception of the farming community regarding climate change}

In line with the results of the trend of rise in maximum temperature during winter and autumn, most farmers in the area share their observation of warming during these seasons. However, they seem to be divided regarding whether they have been able to adjust their farming practices to account for the impacts. Factors like lack of infrastructure, improved technology and access to credit, were cited as the main factor inhibiting adaptation.

Changes in timings of the cropping seasons was interpreted by the farmers to have stemmed from two causes: first, the changes in crop duration due to the adaptation of improved varieties and increases in cropping intensity resulting in the need to accommodate more crops and second, the rise in maximum temperature during winter and autumn seasons which have resulted in quicker harvesting and changes in sowing time. Even though the farmers seem to be unable to tell which among the two is more predominant cause of the shifts in timings, most farmers in the basin believe that warming during winter is a real trend that they have themselves observed over the years in terms of snowline, amount of frost and mist, etc.

Similarly, no defined changing trend of total amount of rainfall was reported but the inhabitants seem to believe that the erratic nature of rain and the occurrence of extreme events like drought and flooding have increased over time. This, they pointed out, was evident from the fluctuations in agricultural productions in spite of increasing trend.

Other visible changes in the biotic environment were also reported by the inhabitants of the basin. According to them, the instances of active attack of disease and insects to the standing crops have increased over time. Their interpretation of this was because of the favourable condition of growth and multiplication of disease borne micro-organisms, fungus, bacteria, etc created by rise in maximum temperatures during winter and autumn coupled with weak resistance power of improved crop varieties. They also believe that traditional varieties of legumes like mas (black pulse), bhattamas (soyabeen) and gahat (a legume) were displaced after the use of chemical fertilizers as they could not survive in the new environment.

\section{Influence of Agricultural Practices and Socio- economic Variables on Production Agricultural practices, socio-economic condition and production scenarios}

Agricultural practices followed by the farmers and the underlying social and economic conditions in the production systems of staple crops are presented in Figure 4.

In addition to the growing season climatic condition, the underlying socio-economic condition shows remarkable influence on the crop production in the region. Higher percentage of farmers in the foothills are experiencing increasing trend in production as compared to farmers in the mid-hills. This can be attributed to adequacy of capital and land, use of inorganic fertilizer and pesticides, dependency on agriculture, and availability of irrigation facilities. On the other hand, more pronounced decreasing trend and stagnation in crop yield associated with the lack of resources is compelling about $90 \%$ of the 


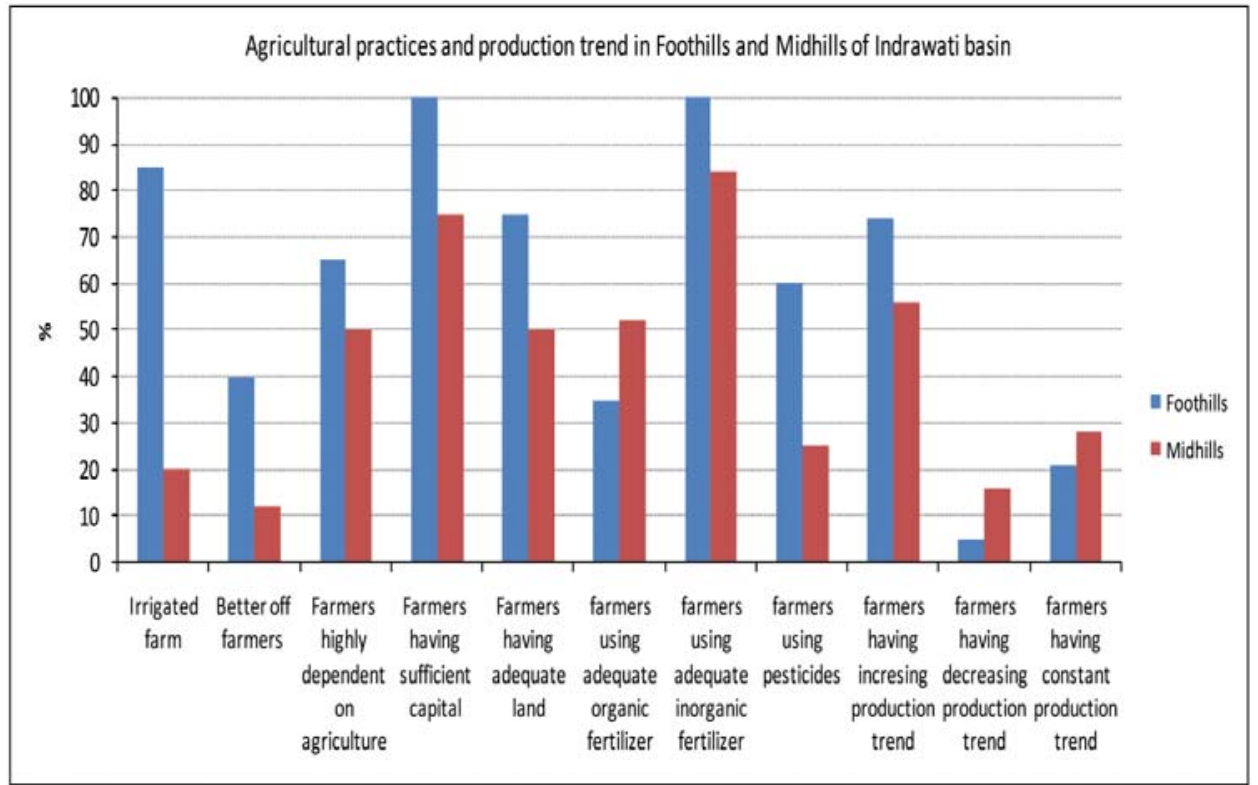

Figure 4. Agricultural Practices and Production Trend.

farmers in the mid-hills to be involved in the subsistence farming. However, quantification of the impact due to climatic variables and socio-economic variables in the crop production has not yet been carried out.

\section{Impact of irrigation}

In the tropical and subtropical region, irrigated agriculture has significantly increased the economic status of the farmers and nearly $40 \%$ of them are generating income from agriculture. In contrast, in the rain-fed agriculture system almost $82 \%$ are bound to be involved in the subsistence farming system. Similarly, in temperate/mid-hills regions, irrigated agriculture systems are relatively more resilient in maintaining production as compared to rain-fed agriculture, irrespective of the resources availability (Figure 5). The percentage of irrigated farms having increasing trend in production is higher than that under rain-fed condition. About $11 \%$

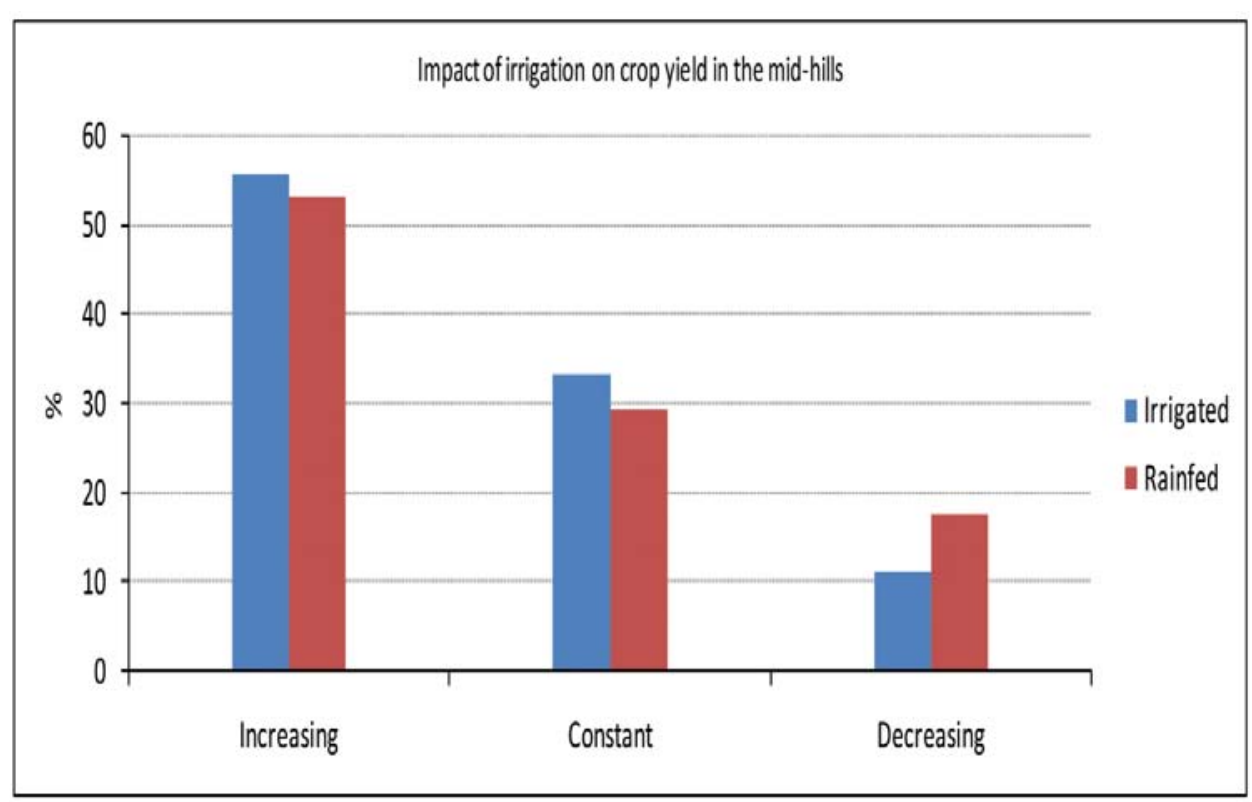

Figure 5. Impact of Irrigation on Crop Yield. of the irrigated farms are experiencing decreasing trend in production while about $18 \%$ of rain-fed farms are experiencing decreasing production trend. Similarly, the production from about $33 \%$ of the irrigated farm is constant (no trend) while only $29 \%$ of the rain-fed farms are able to maintain their production level.

\section{Impact of fertilizers}

It was observed that fertilizer inadequacy in rain-fed subsistence farm of temperate and mid hills can have significant negative impact on production. The impact seems to more pronounce in the soil with low percentage of organic matter. Interestingly, it is found that switching to suitable crop variety can minimize the negative impact of fertilizers inadequacy even in soil with low percentage of organic matter. Similarly, increasing the input of organic fertilizer seems to minimize the negative impact of fertilizer inadequacy to some extent.

Field data reveals that the use of pesticides is also governed by the adequacy of organic fertilizer. Data collected so far show that $80 \%$ of the farmers are unable to use adequate organic fertilizer, insecticides and pesticides. Moreover, during the focus group discussion with the farmers of sample sites it was observed that some of them do not use pesticides even during serious disease outbreak because of the realization of degradation in food taste.

\section{Impact of education level and experts}

The field data collected so far indicates that the farmers who are educated and conscious about the impact of climate change and adopting climate change coping strategies are experiencing increasing trend in the production since last 15 years. Similarly, farmers whose families members are sufficient to carry out the agricultural activities are able to maintain the production level provided all resources are adequate. However, farmers who need to get labor to conduct their agricultural activities are having difficulty to maintain the production level. Education level is found to be inversely proportional to involvement in agriculture.

\section{Conclusion}

The trend analysis of the daily precipitation 
and temperature data for the period of 30 years for the region shows some significant seasonal trends. Overall precipitation does not show much changing trends and no change is observed in the mean precipitation. However, consecutive dry days have increasing trend for winter and autumn with more pronounced effect on winter.

Significant warming trend was observed during winter and autumn with increasing number of hot days. In contrast, no significant trend was observed in any of the temperature indices analysed for spring and summer. Mean diurnal temperature range has increasing trend for winter and autumn associated with increase in the mean maximum temperature.

The analysis of the field data reveals that the agricultural practices and socio-economic variables have a great influence on the crop yield. It is found that farmers having facility of irrigation are more resilient in maintaining production as compared to the rain-fed farms in the same agro-ecological zones. Similarly, farmers in the mid-hills area are facing declining trend in production due to lack of capital, land, adequate fertilizers, and improved seeds pushing about $90 \%$ of them under the subsistence level. In contrast, the foothills farmers are rich in resources, hence the decreasing trend in production is almost negligible. Thus, about $40 \%$ of them are above the subsistence level.

Preliminary data from the sample sites has revealed that farmers depending on local sources of water for irrigation are experiencing decreasing trend of water availability while, no significant trend is observed in areas having perennial irrigation sources. This seems to indicate that global changes have impacted first those who are already marginal.

\section{Acknowledgements}

This paper has been submitted on behalf of the AGloCAP-DoI Research Team; hence, we acknowledge the contribution of all members in the team. The authors also thank UPaRF (UNESCO-IHE Partnership Research Fund) for project funding.

Suman Sijapati, M.E., Irrigation Engineering and Management from Asian Institute of Technology, Thailand. He is the President of INPIM Nepal and also a member of the AGloCAP DoI Research Team. He participated in Hubert Humphrey Fellowship Program at the University of California at Davis (USA).

Corresponding address: suman@sijapati.wlink.com.np

Dinesh Bhatt is a PhD student doing his $\mathrm{PhD}$ from UNESCO IHE under the AGloCAP project.

Corresponding address: dinesh_bhatta@yahoo.com

\section{References}

Fischer, G., M. Shah and H. van Velthuizen, 2002, 'Climate change and agricultural vulnerability', Special Report to the UN World Summit on Sustainable Development, Johannesburg 2002 (International Institute for Applied Systems Analysis, Laxenburg, Austria).

Gunduz, O., V. Ceyhan and Z. Bayramoghu, 2011, 'Influence of the climatic factors on Apricot (Prunus armeniaca L.) yield in the Malatya province of Turkey', Asian Journal of Agricultural Sciences 3(2):150-155.

Hirsch, R.M., J.R. Slack and R. Smith, 1982, 'Techniques of trend analysis for monthly water quality data', Water Resources Research 18(1):107-121.

$\mathrm{Hu}$, Yurong, S. Maskey and S. Uhlenbrook, 2011, 'Trends in temperature and rainfall extremes in the Yellow River Source region, China', Climatic Change March, pp.1-27; doi 10.1007/s10584-011-0066-2.

Ito, T. and T. Kurosaki, 2009, 'Weather risk, wages in kind, and the off-farm labor supply of agricultural households in a developing country', American Journal of Agricultural Economics 91:697-710.

Kendall, M.G., 1975, Rank Correlation Methods (4th edition), London: Griffin.

López-Moreno, J., S. Vicente-Serrano, M. AnguloMartínez, S. Beguería and A. Kenawy, 2009, 'Trends in daily precipitation on the northeastern Iberian Peninsula, 1955-2006', International Journal of Climatology 30:1026-1041; doi:10.1002/joc.1945

Mann, H.B., 1945, 'Nonparametric tests against trend', Econometrica 13:245-259.

Moberg, A. and P.D Jones, 2005, 'Trends in indices for extremes in daily temperature and precipitation in central and western Europe, 1901-99', International Journal of Climatology 25:1149-1171.

Nelson, G.C., M.W. Rosegrant, J. Koo et al, 2009, Climate Change: Impact on Agriculture and Costs of Adaptation, Washington, DC: International Food Policy Research Institute. URL: http://dx.doi. org/10.2499/o896295354.

Rajkarnikar, G., 2000, 'Initial assessment of resource base in Indrawati river basin Nepal', Kathmandu: Water and Energy Secretariat (WECS) and the International Water Management Institute (IWMI).

Sen, P.K., 1968, 'On a class of aligned rank order tests in two-way layouts', Annals of Mathematical Statistics 39:1115-1124.

UN Millenium Project, 2005, Investing in Development. A Practical Plan to Achieve the Millenium Development Goals, Report to the UN Secretary General, New York.

Vedwan, N. and R.E. Rhoades, 2001, 'Climate change in the Western Himalayas of India: a study of local perception and response', Climate Change Research 19:109-117. 